\title{
Performance Assessment of 1.20 MLD Sewage Treatment Plant
}

\author{
Sharma Dinesh, Sharma Devinder, Vikram Singh
}

\begin{abstract}
A study was carried out to evaluate the performance of Sewage Treatment Plant in Ghumarwin area and the following conclusions have been drawn. The ranges of physical, chemical and biological characteristics of waste water quality which is in the permissible limits given by waste water/sewage effluent standard as per pollution control board. The results of parameters i.e. $\mathrm{pH}, \mathrm{BOD}, \mathrm{COD}$, TSS, Oil \& Grease after the sewage treatment is under the standards limits. The standards of sewage treatment parameters $\mathrm{pH}, \mathrm{BOD}, \mathrm{COD}, \mathrm{TSS}$, Oil \& Grease up to $5.5-9.0,30 \mathrm{mg} / \mathrm{l}, 250 \mathrm{mg} / \mathrm{l}, 100 \mathrm{mg} / \mathrm{l}$ and $10 \mathrm{mg} / \mathrm{l}$. The results of $\mathrm{pH}, \mathrm{BOD}, \mathrm{COD}, \mathrm{DO}$ and SS were 7.0 to $7.5,18.0$ to $22.0 \mathrm{mg} /$, 150.0 to $165 \mathrm{mg} / \mathrm{l}, 5.0$ to $6.0 \mathrm{mg} / \mathrm{l}$ and 50.0 to $56.0 \mathrm{mg} / \mathrm{l}$, which are within the permissible standard limits . In the present study, all the above parameters were compared with the limits given by Pollution Control Board and it was found that all parameters are with in the acceptable limits. Hence it is concluded that performance of Sewage Treatment Plant is good and in working condition.
\end{abstract}

Keywords: $p H, B O D, C O D, D O, T S S$, Oil and Grease

\section{INTRODUCTION}

Waste water is waste liquid discharged from commercial properties, industry, agriculture industry, domestic residences, which may contains some of the contaminants which results from the mixing of wastewater from different sources (website-www. pollutionarticles.blogspot.com, 2009-10). Waste water can be classed as commercial, sanitary, agricultural, industrial, or surface runoff based on its origin. The Term waste water need to be separated from the term Sewage, the terms "Sewage" and "Sewerage" are many interchanged (Funk et al., 1960). Sewage is contaminated with feces or urine. The sewage generates from hospitals, residences, industries, offices etc. Sewage includes domestic, municipal, or industrial liquid waste products disposed off, usually via a pipe or sewer (sanitary or combined), Domestic sewage contains a wide variety of dissolved and suspended impurities and is the primary source of pathogens (disease-causing microorganisms) and putrescible organic substances. Because pathogens are excreted in feces, all sewage from cities and towns is likely to contain pathogens of some type, potentially presenting a direct threat to public health. Putrescible organic matter presents a different sort of threat to water quality during recent years.

Revised Manuscript Received on February 05, 2020.

* Correspondence Author

Sharma Dinesh, Assistant Professor, SIRDA Institute of Engineering Technology, Sundernagar, Himachal Pradesh, India.

Sharma Devinder, Director/Principal, SIRDA Institute of Engineering Technology, Sundernagar, Himachal Pradesh, India.

Vikram Singh, SIRDA Institute of Engineering Technology, Sundernagar, Himachal Pradesh, India.

(C) The Authors. Published by Blue Eyes Intelligence Engineering and Sciences Publication (BEIESP). This is an open access article under the CC BY-NC-ND license (http://creativecommons.org/licenses/by-nc-nd/4.0/)
Sewage/wastewater treatment is vital process in the modern industrial world, along-side this, more than $97 \%$ of water is stored in saline and only 3\% in fresh, however only less than $1 \%$ is available for consumption. Zhou and Smith introduced the most beneficial approach to sewage treatment which is the Process that releases the most minimal amount of pollutant into environment. The first wastewater treatment attempt was releasing the pollutants into rivers, which were the sources of most water supplies. In 1871, this problem drew the public's attention to itself when the future king Edward VII caught typhoid fever while staying at a house in Yorkshire. The reason was traced to bad drainage and his illness resulted in immediate efforts to improve the prevailing sanitary system and so by the 19th century large cities realizes that they must reduce the water pollution which they release into the environment. Sewage system began to designed and created after Louis Pasteur and his colleagues proved that the bacteria which lived in sewer could causes infectious diseases. Over-all, NIRAJ S. and TOPARE [3] introduced three main objectives in Sewage treatment:

i. The Evacuation of postponed particles and floatable materials

ii. The treatment of organic elements in the wastewater

iii. The removal of micro-organics which may be cause of dangerous diseases.

Sewage Treatment Plant is a facility designed to receive the waste from domestic, commercial and industrial sources and to remove materials that damage water quality and compromise public health and safety when discharged into water receiving systems. It includes physical, chemical, and biological processes to remove various contaminants depending on its constituents. Using advanced technology, it is now possible to re-use sewage effluent for drinking water.

\section{EXPERIMENTAL PROGRAM}

This part of research paper describes the materials used and the methods followed during the course of the present study. It explains the selection of sampling points, sampling procedure followed, frequency of sampling and wastewater quality analysis and the parameters analyzed such as $\mathrm{pH}$, Dissolved Oxygen, Biochemical Oxygen Demand etc. It also lists the components of Sewage Treatment Plant and the flow diagram of the STP.

The Sewage treatment plant at Ghumarwin has been designed to treat 1.2 MLD of sewage from Ghumarwin town area.

Capacity of Plant: 1.2 MLD.

TABLE 2.1. Components of Sewage Treatment Plant

\begin{tabular}{|c|c|c|c|}
\hline Sr.no. & Unit & Nos & Sizes/capacity (m) \\
\hline
\end{tabular}


Performance Assessment of 1.20 MLD Sewage Treatment Plant

\begin{tabular}{|c|c|c|c|}
\hline 1 & Inlet chamber & 1 & $1.50 * 1.50 * 1.50$ \\
\hline 2 & Manual screen channel & 2 & $1.60 * 1.50 * 0.75$ \\
\hline 3 & Manual grit channel & 2 & $11.65 * 1.00 *(0.60+0.75)$ \\
\hline 4 & Extended Aeration Tank & 1 & $16.80 * 3.50$ \\
\hline 5 & Secondary Clarifier & 1 & $5 * 16.80 * 3.50$ \\
\hline 6 & Flash Mixer & - & - \\
\hline 7 & Clarriflocculator & - & - \\
\hline 8 & Lime closing tank & - & - \\
\hline 9 & Sludge well & - & - \\
\hline 10 & Bleaching dozer & 1 & $1.00 * 1.00 * 1.00$ \\
\hline 11 & Septic tank \& Soak pit & 1 & $44.60 * 5.50 * 3.50$ \\
\hline
\end{tabular}

\begin{tabular}{|l|l|l|}
\hline 2. & BOD & $30 \mathrm{mg} / \mathrm{ltrs}$ \\
\hline 3. & COD & $250 \mathrm{mg} / \mathrm{Ltrs}$ \\
\hline 4. & TSS & $100 \mathrm{mg} / \mathrm{Ltrs}$ \\
\hline 5. & Oil \& Grease & $10 \mathrm{mg} / \mathrm{Ltrs}$ \\
\hline
\end{tabular}

3.1 Results of Flow of Waste water/ Effluent and its analysis report from January 2017 to April 2017

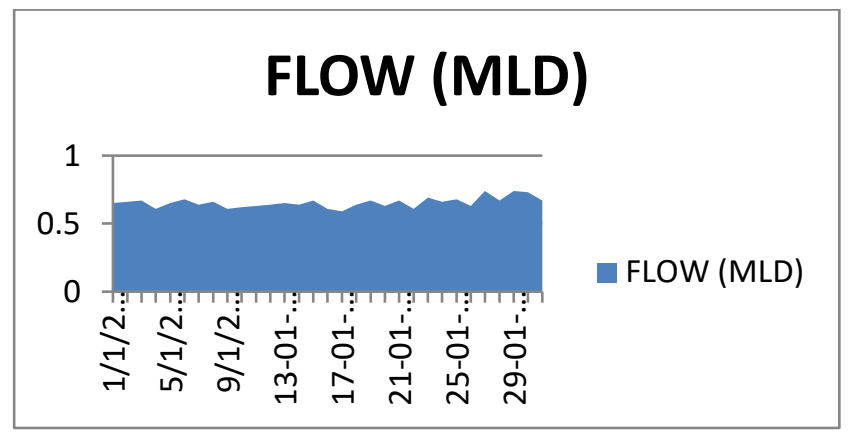

Fig.31. FLOW (MONTH-JAN.2017)

\begin{tabular}{|c|c|}
\hline SR.NO. & MECHANICAL UNITS \\
\hline 1 & C.I. gates. \\
\hline 2 & Manual bar screens \\
\hline 3 & Fixed type slow speed aerators \\
\hline 4 & Clarifier /Sludge scrappers \\
\hline 5 & Bleaching dozer \\
\hline 6 & Flash mixer \\
\hline 7 & Lime mixer \\
\hline 8 & Sludge Agitator \\
\hline 9 & Sludge recycle pump \\
\hline 10 & Filter press feed pump \\
\hline 11 & Filter press \\
\hline
\end{tabular}

\section{SEWER NETWORK:}

Complete sewer network length $=19.20 \mathrm{Km}$.

No. of manholes $=1003$ Nos. Connection released $=490$ No

\section{Sampling Locations}

2.1 Samples were collected at every unit of raw water inlet and at outlet

\subsection{Sampling Periods}

Samples were collected daily at inlet and outlet from January to April . Flow is measured and lab analysis of samples collected were done for determining $\mathrm{pH}$, BOD, COD, SS and DO.

\section{RESULTS AND DISCUSSIONS}

In this chapter the data from various experiments and observations have been compiled and subject to critical examination to arrive at qualitative conclusions. It describes the results of wastewater quality parameters analyzed and the results have been given in graphical forms. The average, maximum, minimum and standard deviation values have been given in the figures .Waste water / sewage effluent standards as per Pollution control board are given in table 3.1.

Table 3.1 - Waste Water / Sewage Effluent Standards as per Pollution control board

\begin{tabular}{|l|l|l|}
\hline $\begin{array}{l}\text { Sr. } \\
\text { No. }\end{array}$ & Parameters & Standards \\
\hline 1. & $\mathrm{pH}$ & $5.5-9.0$ \\
\hline
\end{tabular}

Flow=0.55 MLD, Maximum Flow=0.74 MLD, Average Flow=0.65 MLD

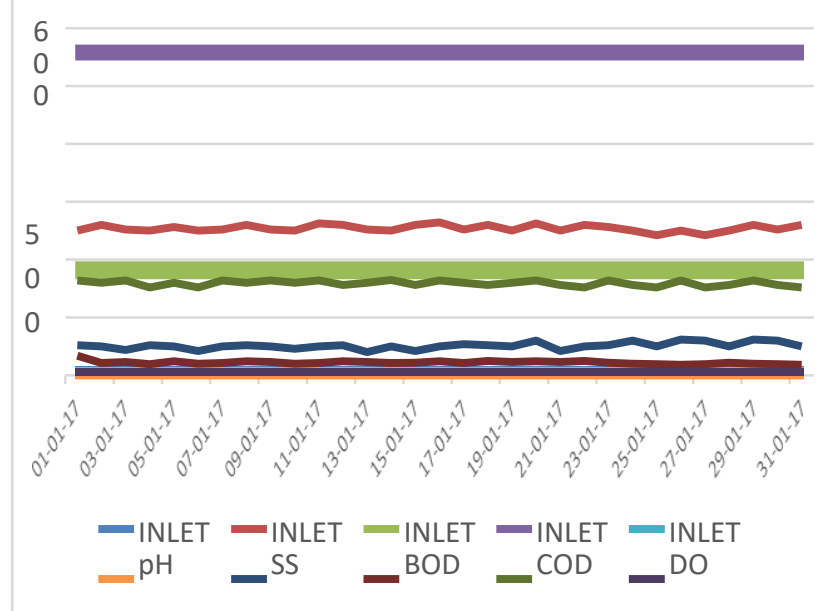

Fig.3.2. ANALYSIS REPORT OF 1.20 MLD (JAN.2017)

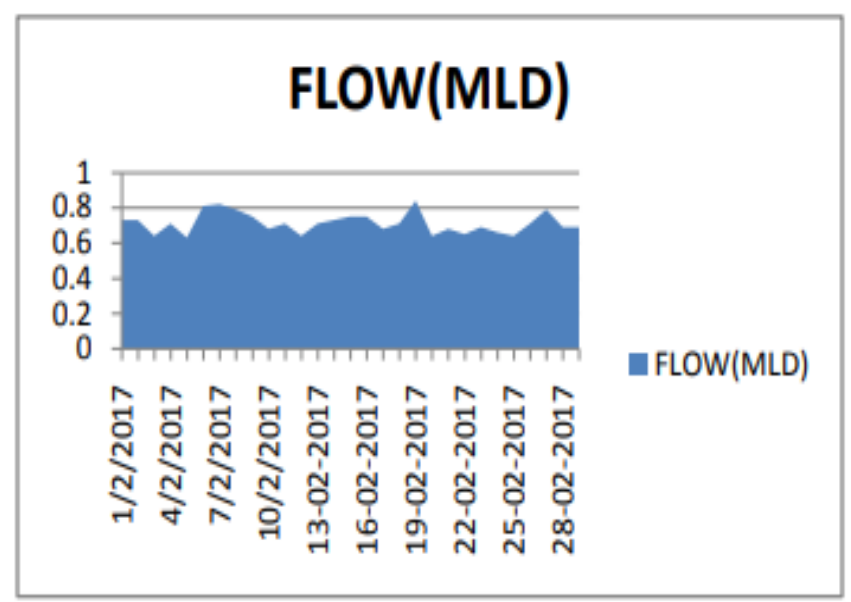

Fig.3.3. FLOW (MONTH-FEB.2017) 


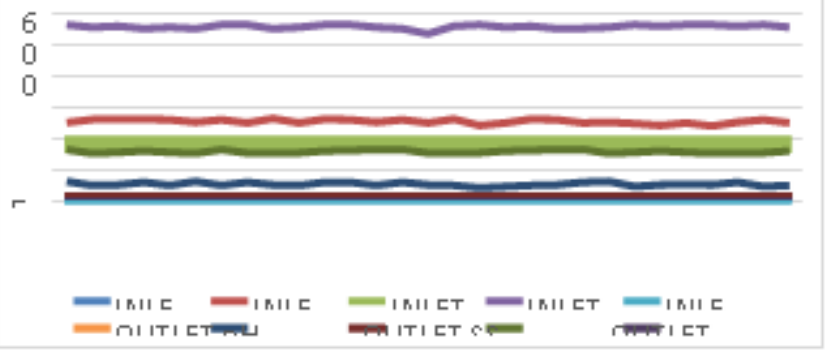

Fig 3.4 ANALYSIS REPORT OF 1.20 MLD (FEB.2017)

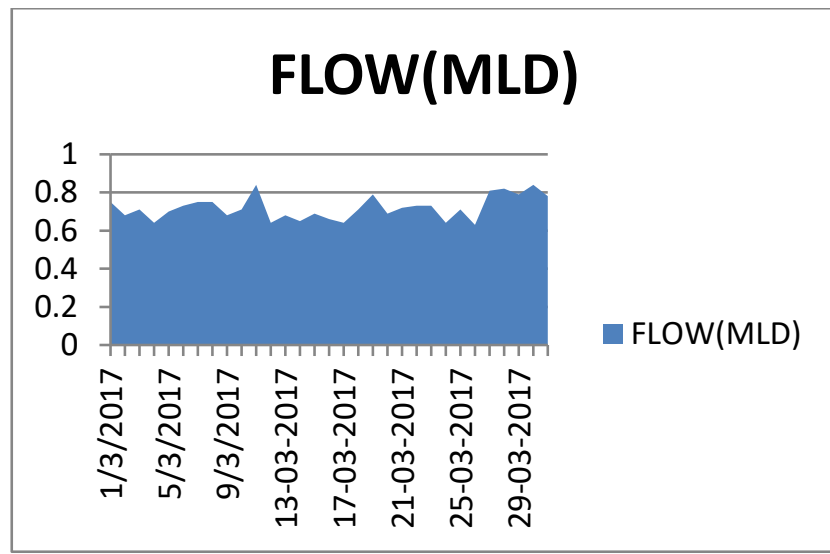

Fig.3.5. FLOW (MONTH-MARCH.2017)

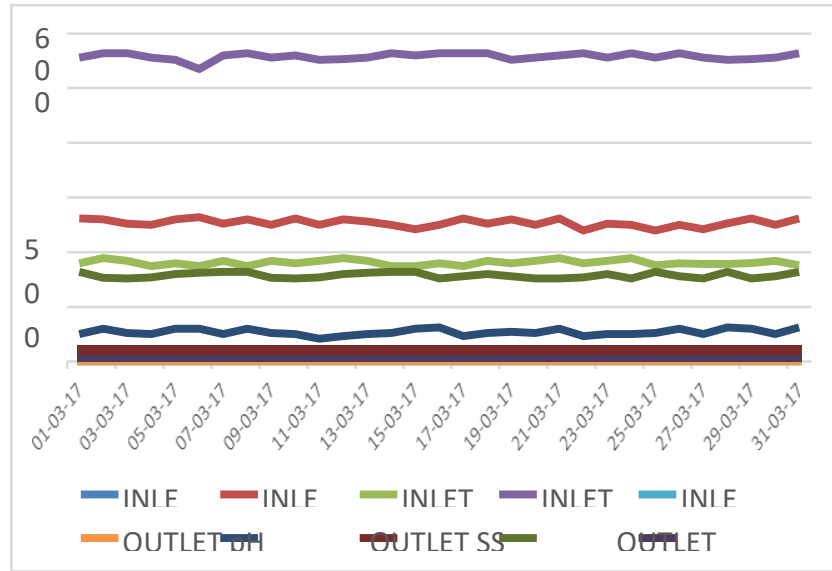

Fig 3.6 ANALYSIS REPORT OF 1.20 MLD (MARCH.2017)

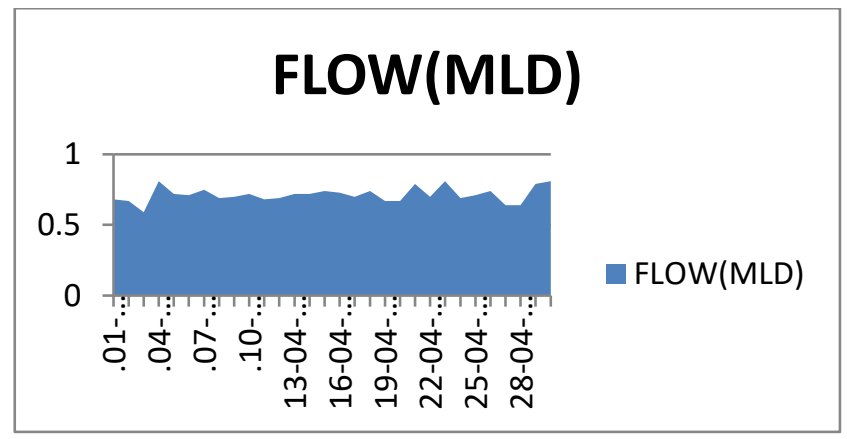

Fig.3.7. FLOW (MONTH-APRI (2017)

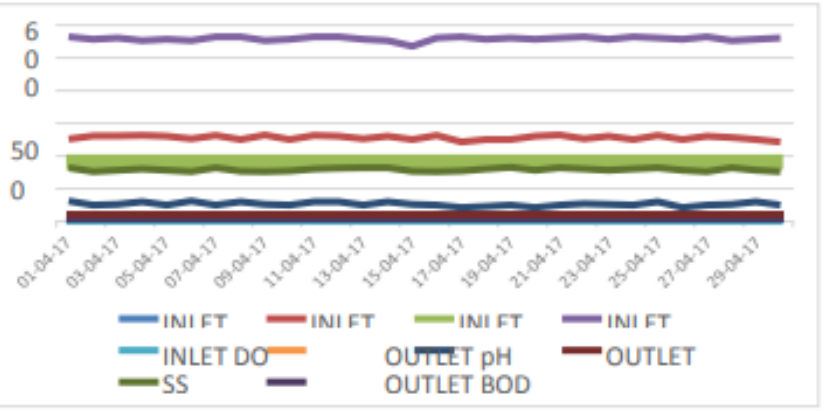

Fig 3.8 ANALYSIS REPORT OF 1.20 MLD (April 2017)

\subsection{Discussion of Results}

\subsubsection{Biochemical Oxygen Demeand (BOD)}

During the study it was recorded that BOD varies from 160$200 \mathrm{mg} / \mathrm{l}$ for influent of Sewage Treatment Plant Ghumarwin. The Highest value of BOD for influent clearly indicates that this highest value is attributed to heavy organic and inorganic loading. Average BOD was recorded as $185 \mathrm{mg} / \mathrm{l}$ for the influent of Sewage Treatment Plant; high average value of BOD for the Sewage Treatment Plant Indicates the Degree of pollution of influent. BOD value for effluent was in the range of $30 \mathrm{mg} / \mathrm{l}$ of Sewage Treatment Plant. Average BOD value for effluent recorded was $18 \mathrm{mg} / \mathrm{l}$ of Sewage Treatment Plant. It was observed that average BOD value for effluent of Sewage Treatment Plant was under permissible limit according to "CPCB effluent discharge standards into Inland Surface Water" after introduction of MLSS. (CPCB,2016) [11].

\subsubsection{Chemical Oxygen Demand (COD)}

In the present study COD value varies from 400-600mg/l for the influent of Sewage Treatment Plant. Highest value of COD was due to the heavy organic loading. Average influent value of COD recorded was $550 \mathrm{mg} / \mathrm{l}$ for the influent of Sewage Treatment Plant. It has been observed that average COD value i.e. $93.02 \mathrm{mg} / \mathrm{l}$ for effluent of Sewage Treatment.

\subsubsection{Dissolved Oxygen (DO)}

It is recorded that DO vary from $4.5-6.8 \mathrm{mg} / \mathrm{l}$ for Aeration Tank. Average DO value was recorded as $5.6 \mathrm{mg} / \mathrm{l}$ for Aeration Tank.

\subsection{4 $\mathrm{pH}$}

During the course of the study it was recorded that $\mathrm{pH}$ varies from acidic to alkaline 7.2 -8.3 for influent of Sewage Treatment Plant. Average $\mathrm{pH}$ value of the influent was recorded as 8.23 for Sewage Treatment Plant indicating that influent was alkaline in nature for the Sewage Treatment Plant

Also during the course of study it was recorded that $\mathrm{pH}$ varies from $7.0-7.8$ for effluent which indicates that effluent during the duration of study was alkaline in nature. Average $\mathrm{pH}$ value of the effluent was recorded as 7.41 for Sewage Treatment Plant which clearly shows that effluent was alkaline in nature. Also average $\mathrm{pH}$ value of the effluent for Sewage Treatment Plant was under Permissible Limit according to CPCB Effluent Discharge Standards into Inland Surface Water. (CPCB, 2016) [11] 


\section{Performance Assessment of 1.20 MLD Sewage Treatment Plant}

\section{CONCLUSIONS AND RECOMMENDATION}

A study was carried out to evaluate the performance of Sewage

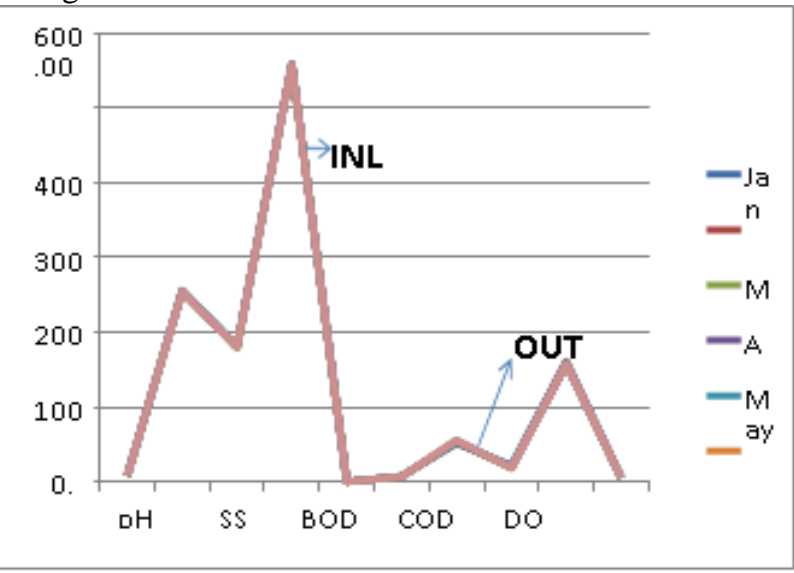

Fig4.1 Average pH, SS, BOD, COD, DO

Treatment Plant in Ghumarwin area and the following conclusions have been drawn. The ranges of physical, chemical and biological characteristics of waste water quality which is in the permissible limits given by waste water/sewage effluent standard as per pollution control board. The results of parameters i.e. $\mathrm{pH}$, BOD, COD, TSS, Oil \& Grease after the sewage treatment is under the standards limits. The standards of sewage treatment parameters $\mathrm{pH}, \mathrm{BOD}, \mathrm{COD}$, TSS, Oil \& Grease up to 5.5$9.0,30 \mathrm{mg} / \mathrm{l}, 250 \mathrm{mg} / \mathrm{l}, 100 \mathrm{mg} / \mathrm{l}$ and $10 \mathrm{mg} / \mathrm{l}$. The results of $\mathrm{pH}, \mathrm{BOD}, \mathrm{COD}, \mathrm{DO}$ and SS for the present study are 7-7.5, $18-22 \mathrm{mg} / \mathrm{l}, 150-165 \mathrm{mg} / \mathrm{l}, 5-6 \mathrm{mg} / \mathrm{l}$ and $50-56 \mathrm{mg} / \mathrm{l}$ as shown in fig 4.1, which are not harmful and within existing standards limits. In the present study, all the parameters are compared with the limits given by Pollution Control Board and it is found that all the parameters are within the acceptable limits. Hence it is concluded that performance of Sewage Treatment Plant is good and it is working very well.

\section{RECOMMENDATIONS}

Overall performance of Sewage Treatment is fine but some recommendations are given below:

1. Proper maintenance and cleaning of Sewage Treatment Plant is needed on every year.

2. It is required to provide chlorinator device for proper chlorine dose in chlorine contact tank.

3. Alternative power source is required for emergencies of power cut because without aeration unit working DO level may decrease which may result in failure of treatment process.

4. Provision of discharge measuring device at inlet is needed.

\section{FUTURE SCOPE}

1. Bacteriological test is required to be conducted in future when there is increase in Sewage Treatment Plant capacity.

2. It needs to be evaluated weather effluent of changed parameters by CPCB can be achieved when Two Plants will work with full capacity.

3. Other parameters like Nutrients (Phosphorus, Nitrogen) and TDS need to be evaluated.
The study needs to be replicated for the nearby towns of Himachal Pradesh

\section{REFERENCES}

1. 1991 Census of India/Accessed (2001)

2. www.mapsofindia.com, "Himachal Pradesh Location Map".

3. www. pollutionarticles.blogspot.com, "Wastewater from different sources (2009-10)",

4. Funk, “A Standard Dictionary Int.ed.” New York, P- 1152. (1960).

5. NIRAJ S. and TOPARE, "Evaluation and Objectives of Sewage Treatment Plant".

6. Mahesh Kawale, Er. Devendre Doare \& Er.Pravin Tupe, "Performance evaluation of existing ASP \& SBR (30 MLD capacity) Sewage Treatment Plant's at PCMC, Pune $(\mathrm{MH})$ - A case study. American Journal of Engineering Research Volume- 4, Issue-8, www, ajer.org." (2015).

7. Kavita N. Choksi, Margi A Sheth, Darshan Mehta, "To evaluate the performance of Sewage Treatment Plant: A Case study on Anjana Sewage Treatment Plant. International Research Journal of Engineering and Technology (IRJET)," Volume; 02 Issue: 08 Nov2015, www,irjet,net.

8. Prerna Sharma, "A Comparative Study of Sewage Treatment Plants with different technologies in the Vicinity of Chandigarh City." Post Graduate Environmental Engineering Department PEC University of Technology. https://www.scribd.com/. (2013).

9. Nidhi \& Dr. Govind Pandey, "Performance Evaluation of 15 MLD Sewage Treatment Plant at Gorakhpur. International Journal for Scientific Reasearch \& Devetopment Vol. 4, Issue 02," https://www.scribd.com/. (2016).www.dutchwatersector.com/newsevents/news/15338-first-of-three-nereda-wastewater- tratment-plantsin-ireland-took-flow.html

10. Central Pollution Control Board, "GUIDE MANUAL: WATER AND WASTEWATER ANALYSIS.” (2016).

11. http://cpcb.nic.in/upload/Latst_67_guidemanualw\&wwanalysis.pdf (Accessed 2-12-2017)

12. HPIPH Organization report: On Assessment of Sewage Treatment Plants in Himachal Pradesh", prepared in May 2016.

13. Google Earth. https://earth.google.com/Accessed (10-2-2017).

14. Metcalf and Eddy, "Wastewater Engineering, treatment and reuse," New Delhi: Tata McGraw -Hill Publishing Company Limited, (2003).

15. Ground Water Information Booklet Ghumarwin, Distt. Bilaspur, Himachal Pradesh. Government of India Ministry of Water Resources. 